\title{
12
}

\section{RESTART Before It is Too Late}

Johnny and Richardson - two athletic men who knew every back-alley in Port-Au-Prince-were waiting in the arrival hall at the Toussaint Louverture International Airport. Sveinung and Rannei Johanne, his then 18-year-old daughter, had just landed after a colorful flight on a plane that was so small that even though they sat on isle 3, they were in the middle of the plane, and even though they sat together, both of them had a window seat. Johnny and Richardson were hosts working for The Plastic Bank-the company Sveinung and Rannei Johanne were visiting, and their temporary role as "bodyguards" was not just for show. This was an unstable time in Haiti-a place where instability is the rule rather than the exception. However, the level of tension was even higher than normal, as the 120-day period of the interim president, Jocelerme Privert, had expired. The president had lost public confidence but did not intend to let go of power. There was political turmoil, and chaos on the streetsviolence had escalated, and just a week before Sveinung and his daughter arrived in Port-Au-Prince, a Swedish tourist was shot in broad daylight.

The local management team from The Plastic Bank, with Sephora Pierre-Louis as their natural leader-had notified Sveinung that they needed the protection that the two men could offer. Upon arrival, they 
sat in a car with dark-tinted windows and sped up toward The Plastic Bank's headquarters on the island. This company, which we have discussed earlier in the book, had become widely known for its innovative business model that made plastic into a currency for poor collectors of plastic. On an invitation from the founder, David Katz, Sveinung traveled to Haiti to study the company's business model up close. Not at least, he wanted to understand more about how such a business model could work in the unstable and chaotic context of Haiti in the year 2016.

We started the book with the story of our stopover in Rwanda, where it is forbidden to bring plastic into the country. Prohibition of some kinds of plastic has since been introduced in many other countries, and the plastic problem that The Plastic Bank is trying to solve has worsened worldwide. This has also resulted in increased attention to the problem. It is extremely hot in Haiti, and people have to buy water in bottles or in bags. Every day, five million small plastic bags of water are consumed in the country and most of the bags are discarded on the ground. The renovation system does not work, and streets, rivers and canals are therefore inundated with plastic bottles, plastic bags, polystyrene and other waste. People burn waste on the streets, and from the mountains around the city, one can see many small and large bonfires at any time. In Haiti, The Plastic Bank has developed 30 recycling stations where people can trade plastic for cash, charging of their cell phones or other services. Approximately 3500 people currently collect plastic, and the goal of The Plastic Bank is to establish 200 such recycling stations in various locations in Haiti-also beyond the metropolis of Port-au-Prince.

People in Haiti are entrepreneurial — they get up early and walk a long way to work and feed their families. Early in the morning, people get together on the streets to sell bananas, used shoes, car parts and all other imaginable products and services. By turning plastic into a currency and making it possible for people to trade plastic for money and other services, The Plastic Bank is creating value for many people. Moreover, the company thus helps plastic from ending up in the sea every time it rains. The vision is to establish this business model in many countries, with Asia as the next stop, where the problems related to plastic and poverty are 
substantial. In preparation for its entry into the Asian market, The Plastic Bank is also collaborating with IBM in order to build a blockchain-based bank for the poor-thus getting one step closer to become an actual "bank", as indicated by the company's name.

One of the challenges to succeed is to get the major companies in the world to buy and use recycled-or rather upcycled-plastic. The current low oil prices imply that the production of virgin plastic is cheap, which in turn reduces the demand for recycled plastic. Companies therefore need customers to pay more for shampoo bottles, sunglasses and clothing that are made by Social Plastic. For the time being, companies rely on customers and other stakeholders agreeing to pay a premium for Social Plastic, while The Plastic Bank continues to reduce its costs and create economies of scale in order to be cost-effective. Still, The Plastic Bank is driving down the costs associated with its production and has managed to secure many large contracts in recent years. For instance, in late 2017 , the company entered into a comprehensive contract with the German chemical and consumer goods company Henkel, which intends to use Social Plastic-branded materials in its products.

In order to make its operations more efficient, The Plastic Bank is trying to make plastic collectors in Haiti cooperate. As a pilot project, the company has just established three cooperatives in which eight collectors work together. In this way, the collectors are able to collect more plastic, and they may get better bargaining power vis-à-vis those who buy the plastic. Sveinung and Rannei Johanne went to meet two of these cooperatives to see how they worked. In blazing sunshine, in an environment still characterized by the major earthquake that killed over 200,000 people in 2010, a group of collectors worked in the shadow of ragged blankets that they had hung as protection. A woman with a large pipe in her mouth removed the labels on the bottles, while another washed the bottles. A third person sorted the different types of plastic in big bags, while four others were out collecting bottles.

All of them lived in the same area, where children played and slept between large sacks of plastic. Few people can read, write or do simple mathematics. Therefore, each cooperative has an accountant who keeps 
track of how much each member contributes, not to mention how much the cooperative will get when delivering the plastic to the recycling stations. The Plastic Bank runs an intensive training program and empowerment is a key consideration. There was consequently particular support and encouragement for the young accountants to complete high school. They were on job rotation so that they shared the tasks of the team, and Sephora and her colleagues worked with training the members of the cooperative as well as the rest of the collectors.

The Plastic Bank collaborates with companies that tear up the bottles mechanically and distributes plastic to customers all around the world. There is hard work at all levels in the organization, from the collectors on the ground to the executives who engage with the major companies that are buyers of its plastic. When Sveinung and Rannei Johanne experienced the operations of the company up close, the pollution problem and the extreme poverty in Haiti seemed overwhelming. At the same time, business models of this kind provide hope that companies can make a difference, both locally and globally. However, that requires many RESTARTs of business models - at the top, the middle and the bottom of the pyramid.

\subsection{It is Not Going to Be Easy}

What is striking about The Plastic Bank and its ambitious and demanding project in Haiti is that it illustrates the difficulty of addressing global sustainability challenges. Haiti can almost serve as a "worst case" example on the triple bottom line. The country's economy is in ruins. Social distress and instability undermine the country's ability to rebuild country properly and create security risks for companies and other organizations contributing to the reconstruction. Environmental destruction and pollution are on the increase because of infrastructural and institutional failure. This all implies that it is very difficult to do business in Haiti. Yet many companies face this reality in trying to contribute to a greener economy. This is the case whether they are working at the bottom of the pyramid or simply working with a global supply chain that involves doing 
business in these markets. The companies involved know firsthand that the social and environmental problems they face in these markets are complex and comprehensive. They will not be solved overnight, and any single company will not solve them.

Leaders in business, politics and civil society are increasingly arguing that a so-called green transition toward more sustainable business is imperative. However, most of them also acknowledge that it will be no walk in the park. This is in line with the research led by Lord Nicholas Stern and his colleagues, who published The New Climate Economy Report (Richardson et al. 2009). Their conclusion is that green growth is possible, but it will require major transformation of business models and patterns of production and consumption. This will also imply that many current business models will disappear and many existing companies will not be able to transition successfully, and consequently not survive. And maybe there are companies and business models that we will be better off without, from the point of view of sustainability. After all, this is innovation in a nutshell—old ways of doing things that served us well for a long time eventually become replaced by something better.

In this book, we have looked at many apparent success stories of green transition: companies that have both the ability and the willingness to implement extensive changes to their business models, in ways that allow them to solve the problems they face while giving them advantages in the markets in which they operate. However, let us not fool ourselves into thinking that such changes or any positive consequences thereof come easily. On the contrary, the changes are demanding and their resulting benefits are not self-evident.

\subsection{Ready, Set, RESTART!}

The good news is that all companies can get started and experiment their way toward more sustainable business models. If we succeed with the green transition, it will happen as a sum of numerous small movements in companies worldwide, in combination with major technological and behavioral shifts that push us in the same direction. Often, the first 
step - to start the RESTART — may be the hardest. Many of the examples in this book illustrate-as we have seen in many other companiesthat movements toward sustainability often spread like ripples in water, both within the company and in the industry.

There is perhaps not a single company described in this book that is truly sustainable. Some of them are however on their way to becoming more sustainable — on the path toward green growth. Some companies have to patiently experiment their way to profitability. Facebook made very little money for a long time, and analysts doubted the company's business model. Spotify is still struggling to make its streaming services profitable, despite considerable growth. We need to be patient with companies that are trying to change their business model in order to align sustainability and profitability - the path toward success is made up by trial and error, and the course needs to be adjusted continuously.

During the week in which we wrote this section of our book manuscript, sustainability investments flowed all over Europe: Google acquired the entire power production of the Norwegian wind power company Norwegian Wind Energy. The financial giant Deutsche Bank divested all its coal investments. A Dutch brewery launched a new type of beer brewed on rainwater, while Belgian researchers presented a technology that makes it possible to make beer from urine. Finally, new numbers were published that showed that more than 20 countries have succeeded in increasing their gross domestic product while at the same time cutting greenhouse gas emissions. All those things happened within a week, and more and more weeks were like that - an indication that the green transition is gaining momentum.

Many large and small steps in the right direction are thus taken all the time, but we need many more. We need change to take place much faster, and we need all the companies that are currently sitting quietly in the boat to start rowing. Hans Bruyninckx, the head of the European Environment Agency, said recently that there is no such thing as being "somewhat sustainable". Companies must become more sustainable, and increasingly sustainable, so that they may eventually become truly sustainable. Importantly, we need them to do so in ways that are compatible with profitability. In other words, it is time for a RESTART. 


\section{Reference}

Richardson, K., Steffen, W., Schellnhuber, H. J., Alcamo, J., Barker, T., Kammen, D. M., \& Stern, N. (2009). Climate change-global risks, challenges \& decisions: Synthesis report. Copenhagen: Museum Tusculanum.

Open Access This chapter is licensed under the terms of the Creative Commons Attribution-NonCommercial-NoDerivatives 4.0 International License (http:// creativecommons.org/licenses/by-nc-nd/4.0/), which permits any noncommercial use, sharing, distribution and reproduction in any medium or format, as long as you give appropriate credit to the original author(s) and the source, provide a link to the Creative Commons license and indicate if you modified the licensed material. You do not have permission under this license to share adapted material derived from this book or parts of it.

The images or other third party material in this chapter are included in the chapter's Creative Commons license, unless indicated otherwise in a credit line to the material. If material is not included in the chapter's Creative Commons license and your intended use is not permitted by statutory regulation or exceeds the permitted use, you will need to obtain permission directly from the copyright holder.

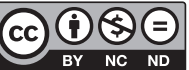

